УДК 159.923:159.922.62 [-027.252:001.891

DOI https://doi.org/10.26661/2310-4368/2020-2-6

\title{
ОСОБЛИВОСТІ СИСТЕМИ ПСИХОЛОГІЧНОГО ЗАХИСТУ ОСОБИСТОСТІ В РІЗНІ ПЕРІОДИ ДОРОСЛОСТІ
}

\author{
Шевченко Н. Ф. \\ доктор психологічних наук, професор, \\ завідувач кафедри педагогіки та психології освітньої діяльності \\ Запорізький національний університет \\ вул. Жуковського, 66, Запоріжжя, Україна \\ orcid.org/0000-0002-5297-6588 \\ shevchenkonf.20@gmail.com \\ Саміташвілі-Бірюк О. О. \\ магістрант кафедри психологіi \\ Запорізький національний університет \\ вул. Жуковського, 66, Запоріжжя, Україна \\ orcid.org/0000-0002-2381-5830 \\ Olesy1@i.ua
}

\begin{abstract}
Ключові слова: механізми психологічного захисту, копінг-стратегії, система психологічного захисту, дорослий вік.
\end{abstract}

У статті викладені результати емпіричного дослідження особливостей системи психологічного захисту особистості в період дорослості. Установлено, що система психологічного захисту особистості в різні періоди дорослості характеризується суб'єктивною динамікою, яка відбивається у взаємозв'язку несвідомих і свідомих компонентів психіки - захисних механізмів і копінг-стратегій. У ході дослідження встановлено, що прояв певних механізмів психологічного захисту залишається майже незмінними в аспекті віку. Найменш варіативні показники: механізми витіснення, проєкції, регресії, компенсації. До найваріативніших показників віднесено механізми заміщення, інтелектуалізації, заперечення, реактивних утворень. Провідними механізмами психологічного захисту в обох періодах дорослого віку виявилися заперечення, витіснення та регресія. У ході вивчення специфіки прояву стилів копінг-поведінки виявлено, що прояв певних стилів залишається майже незмінними в аспекті віку. Найменш варіативні показники: проблемно орієнтований стиль копінгу, орієнтація на соціальне відволікання. До найваріативніших показників віднесено емоційно орієнтований стиль копінгу, орієнтацію на уникнення. Провідними стилями копінг-поведінки в ранньому дорослому віці виявилися проблемно орієнтований стиль копінгу, орієнтація на соціальне відволікання; в середньому віці проблемно орієнтований стиль копінгу, емоційно орієнтований стиль копінгу. Дослідження стратегій поведінкової активності в стресових умовах дозволило виявити, що прояв певних стратегій залишається незмінними в аспекті віку. Найменш варіативні показники: стратегії поведінкової активності А1, Б1, Б. До найваріативніших показників можна віднести стратегії поведінкової активності А. Провідними стратегіями поведінкової активності в стресових ситуаціях виявилися: тип А - в ранньому дорослому віці (гіперактивність, нетерплячість, імпульсивність), тип АБ - у середньому віці (збалансованість, впевненість, емоційна стабільність). За допомогою математикостатистичного аналізу експериментальних даних припущення про те, що 
система психологічного захисту особистості характеризується певною специфікою в різні періоди дорослості, підтвердилося. Ця специфіка відбивається в динаміці прояву несвідомих (механізмів психологічного захисту) й усвідомлюваних (копінг-стратегії) компонентів психіки.

\title{
FEATURES OF THE PSYCHOLOGICAL DEFENSE SYSTEM OF A PERSONALITY IN DIFFERENT PERIODS OF ADULTHOOD
}

\author{
Shevchenko N. F. \\ Doctor of Psychological Sciences, Professor, \\ Head of the Department of Pedagogy and Psychology of Educational Activity \\ Zaporizhzhia National University \\ Zhukovskoho str., 66, Zaporizhzhia, Ukraine \\ orcid.org/0000-0002-5297-6588 \\ shevchenkonf.20@gmail.com \\ Samitashvili-Biriuk O. O. \\ Master's Student at the Department of Psychology \\ Zaporizhzhia National University \\ Zhukovskoho str., 66, Zaporizhzhia, Ukraine \\ orcid.org/0000-0002-2381-5830 \\ Olesy1@i.ua
}

Key words: mechanisms of psychological defense, coping strategies, psychological defense system, adulthood.
The article presents results of an empirical study of features of the psychological defense system of a personality in adulthood. Psychological defense system of an individual is characterized by subjective dynamics in different periods of adulthood, which is reflected in the relationship of unconscious and conscious components of the psyche - defense mechanisms and coping strategies. The study has found that the least variable indicators are mechanisms of repression, projection, regression, compensation. The most variable indicators include the mechanisms of substitution, intellectualization, denial, reaction formation. The leading of psychological defense mechanisms in both periods of adulthood are denial, repression and regression. Studying of specifics of the coping behavior styles has found that the least variable indicators: problem-oriented style of coping, orientation on social distraction. The most variable indicators include emotionally-oriented style of coping, orientation on avoidance. Leading styles of coping behavior in early adulthood are problem-oriented coping style, orientation on social distraction; in middle age - problem-oriented style of coping, emotionally-oriented style of coping. Study of behavioral strategies in stressful conditions has shown that the least variable indicators: strategies of behavioral activity A1, B1, B. The most variable indicators include strategies of behavioral activity A. Leading strategies of behavioral activity in stressful situations: type A - in early adulthood (hyperactivity, impatience, impulsivity), type $\mathrm{AB}$ - sn middle age (balance, confidence, emotional stability). Mathematical and statistical analysis has confirmed the assumption that the psychological defense system of an individual is characterized by certain specifics in different periods of adulthood; this specificity is reflected in the dynamics of manifestation of unconscious (mechanisms of psychological defense) and conscious (coping strategies) components of the psyche. 
Постановка проблеми. Сучасний інформаційний світ пред'являє високі вимоги до стресостійкості дорослої людини. В умовах сьогодення збільшення агресивно насиченої інформації, зміна звичних стереотипів і висока нестабільність у соціальній, економічній і політичній сферах знижують психологічну стійкість особистості до деструктивних впливів. Такі умови передбачають підвищення вимог до адаптаційних можливостей дорослої людини й залежність психологічного добробуту від можливості долати стрес. У ситуації стресу для багатьох людей стає практично звичним стан занепокоєння, напруги, тривоги. Невміння та нездатність долати труднощі є важливим показником психічного й фізичного здоров'я людини.

Оскільки поведінка людини визначається одночасно свідомими й несвідомими процесами, в будь-якій реакції людини співіснують численні й неповторні комбінації копінг-стратегій і механізмів психологічного захисту. Захисна й копінг-поведінка розглядається інтегративно - як єдиний адаптаційний процес, як різні рівні єдиного механізму «захисної системи особистості» (Р.М. Грановська [1], Т.Л. Крюкова [2], О.В. Лапкіна [3], I.М. Нікольська [4], Л.Ю. Суботіна [5]). Система психологічного захисту особистості послідовно формується в онтогенезі й безперервно функціонує в дорослому віці.

Проблема психологічного захисту особистості представлена в працях зарубіжних і вітчизняних науковців (О.Я. Гошовська [6], Е. Еріксон [7], Р. Плутчик [8], А. Фройд [9], 3. Фройд [10], T.C. Яценко [11] та інші). Незважаючи на представленість робіт із проблеми дослідження, аналіз літератури засвідчив, що в центрі психологічного пізнання знаходиться переважно ранній онтогенез, за дефіциту наукових праць, в яких би викладалася проблема психологічного захисту особистості дорослої людини. Вивчення специфіки системи психологічного захисту в різні періоди дорослості необхідні для надання консультативної та психотерапевтичної допомоги.

Мета статті - презентувати результати емпіричного дослідження особливостей системи психологічного захисту особистості в різні періоди дорослості.

Виклад основного матеріалу дослідження 3 обгрунтуванням отриманих наукових результатів. Вивчення феномену психологічного захисту особистості як засобу розв'язання конфлікту між свідомістю та несвідомим розпочато в рамках психоаналітичного напрямку психології $[9,10]$. Дотепер знання щодо психологічного захисту суттєво доповнювались і розширювались працями не тільки послідовників психоаналізу, а й представниками інших психологічних шкіл.
На сучасному етапі психологічний захист розглядається з різних позицій: як такий, що пов'язаний із когнітивними процесами оцінки ситуації; як механізм протистояння неврозу; як переорієнтація в системі особистісних настанов; як захист свідомості від травмувального чинника. У найширшому смислі психологічний захист можна визначити як систему регуляторних механізмів, пов'язаних із суб'єктивним спотворенням психічної реальності, що забезпечують усунення або зведення до мінімуму негативних, травмувальних особистість переживань, які відбивають внутрішні й зовнішні конфлікти, стани тривоги й дискомфорту. Психологічний захист, який є переважно несвідомим процесом оберігання особистості від тривоги й напруги, багатьма авторами пов'язується 3 усвідомленою, цілеспрямованою поведінкою в стресі - копінг-поведінкою $[1 ; 3 ; 5]$.

Аналіз досліджень із проблеми психологічного подолання дозволяє розглядати копінг як свідому поведінку, спрямовану на активну взаємодію 3 ситуацією, - зміна ситуації (піддається контролю) або пристосування до неї (якщо ситуація не піддається контролю). У процесі подолання життєвих труднощів у кожному віковому періоді людина може як набути нового досвіду, розширити діапазон поведінкового репертуару, так і проявити неадекватність своєї поведінки, яка впливає на адаптивну здатність людини [12; 13].

Натепер не існує єдиної класифікації видів копінгу. Підхід, згідно з яким виокремлюються стратегії подолання, $є$ більшою мірою ситуаційним, - суб'єкт залежно від ситуації застосовує конкретні копінг-дії. Визначення стилів копінгу будується переважно на особистісних (темпераментних, характерологічних) підставах, менш залежних від особливостей стресової ситуації. Під час виділення різноманітних стратегій подолання більшість авторів схильні погоджуватися в тому, що існують два стилі копінг-поведінки: емоційно орієнтований i проблемно орієнтований, який пов'язаний з емоційним реагуванням, регулюванням стресу й активним розв'язанням проблеми [2; 4].

Дорослість $\epsilon$ найменш вивченим періодом онтогенезу, для якого характерні найвищий рівень розвитку духовних, інтелектуальних, творчих i фізичних здібностей людини. На цьому етапі виникають специфічні особливості Я-концепції, спонукальної та емоційної сфер особистості, змінюється спосіб життєдіяльності (створення сім'ї, сімейні стосунки, батьківські функції, кар'єра, творчі досягнення тощо). Дорослість розглядається як час безперервного зростання, а розвиток дорослої людини характеризується як основа розв'язання проблем попередніх періодів: набуття автономності й довіри, ініціативи, працездатності й ідентичності. 
На сучасному етапі розвитку науки більшість науковців, які займаються дослідженням проблеми психологічного захисту, схильні інтегрувати психологічний захист і копінг в єдину систему. Система психологічного захисту особистості є спільним функціонуванням несвідомих та усвідомлюваних компонентів психіки, спрямованих на усунення суб'єктивного дискомфорту особистості в ситуаціях різного ступеня інтенсивності стресу. У дорослому віці формуються стійкі комплекси захисних механізмів, серед яких певні механізми $є$ провідними, а інші - додатковими, допоміжними. Система психологічного захисту особистості в різні періоди дорослості характеризується суб'єктивною динамікою, яка відбивається у взаємозв'язку несвідомих і свідомих компонентів психіки - захисних механізмів і копінг-стратегій $[1 ; 3 ; 5 ; 6 ; 11]$.

Метою емпіричного дослідження було вивчення психологічних особливостей системи психологічного захисту особистості в різні періоди дорослості (ранній дорослий вік, середній вік). В основу дослідження було покладено припущеення про те, що система психологічного захисту особистості в різні періоди дорослості характеризується певною специфікою, яка полягає в динаміці прояву несвідомих (механізмів психологічного захисту) й усвідомлюваних (копінг-стратегії) компонентів психіки.

Дослідницьку вибірку склали 133 особи дорослого віку. Розподіл респондентів за віковими групами здійснено на основі періодизації Б.Г. Ананьєва:

- I група: перший період дорослості (ранній дорослий вік): 22-35 років - чоловіки (30 осіб), 21-35 років - жінки (30 осіб);

- II група: другий період дорослості (середній вік): 36-60 років - чоловіки (36 осіб), 36-55 років жінки (37 осіб).

Психодіагностичний інструментарій склали такі методики: «Діагностика типологій психологічного захисту» (авт. Р. Плутчик, адапт. Л.І. Вассерман та інші); «Копінг-поведінка в стресових ситуаціях» (авт. С. Норман, Д.Ф. Ендлер, Д.А. Джеймс, М.І. Паркер; адапт. Т.Л. Крюкової); «Діагностика стратегій поведінкової активності в стресових умовах» (авт. Л.І. Вассерман, Н.В. Гуменюк); математико-статистичні методи обробки експериментальних даних на базі пакету програм IBM SPSS-20.

Розглянемо динаміку прояву механізмів психологічного захисту (за методикою Р. Плутчика). Згідно з отриманими даними в ранньому дорослому віці (I група) найвищі показники зафіксовано за такими механізмами, як регресія $(0,56$ бала, заперечення $(0,51$ бала) і витиснення $(0,50$ бала). У середньому дорослому віці (II група) провідними механізмами психологічного захисту також виявилися заперечення $(0,57$ бала), витиснення $(0,52$ бала) й регресія $(0,51$ бала). Водночас виявлено певні вікові зміни в показниках механізмів психологічного захисту.

Механізм заперечення значною мірою виражений у II групі респондентів (I - 0,51 бала; II 0,57 бала). Дія цього механізму проявляється в запереченні тих аспектів зовнішньої реальності, які, бувши очевидними для оточення, не приймаються та не визнаються самою особистістю. Цей засіб захисту реалізується в конфліктах будь-якого роду й характеризується зовні виразним спотворенням сприйняття дійсності.

Механізм витіснення (репресії) також має тенденцію до підвищення з віком (I - 0,50 бала; II - 0,52 бала). За допомогою витіснення неприйнятні для особистості імпульси - бажання, думки, почуття, які викликають тривогу, - стають несвідомими. На думку більшості дослідників, цей механізм лежить в основі дії інших захисних механізмів особистості. Найчастіше витісняються багато властивостей, особистісні якості й вчинки, які не роблять особистість привабливою у власних очах і в очах інших.

Механізм регресіі виявився характернішим для періоду ранньої дорослості - 21-35 років (I 0,56 бала; II - 0,51 бала). За цією формою захисної реакції особистість під час дії фруструючих факторів замінює собою рішення суб'єктивно складніших завдань відносно простішими й доступнішими в сформованих ситуаціях. Використання простіших і звичніших поведінкових стереотипів суттєво збіднює загальний (потенційно можливий) арсенал переважання конфліктних ситуацій.

Механізм компенсаиії також виявився досить вираженим в обох досліджуваних групах (I 0,49 бала; II - 0,45 бала) з тенденцією до зниження 3 віком. Цей механізм психологічного захисту проявляється у спробах знайти відповідну заміну реальної чи уявної нестачі, дефекту нестерпного почуття іншою якістю, найчастіше за допомогою фантазування або привласнення собі властивостей, чеснот, цінностей, поведінкових характеристик іншої особистості. Переважання цього типу психологічного захисту в ранньому дорослому віці можна пояснити характерним для цього віку пошуком ідеалів у різних сферах життєдіяльності. Компенсація дозволяє знаходити баланс між інформацією із соціуму й уявленнями про себе, підтримуючи самооцінку.

Прояв механізму проєкції виявився майже однаковим в обох досліджуваних групах (I 0,36 бала; II - 0,38 бала). В основі проєкції лежить процес, за допомогою якого неусвідомлювані й неприйнятні для особистості почуття та думки локалізуються зовні, приписується іншим людям і таким чином стають ніби вторинними. 
Показники механізму заміщення з віком суттєво знижуються (I - 0,47 бала; II - 0,37 бала). Заміщення як психологічний захист дозволяє справлятися з напругою шляхом ії вираження в дії. Дія цього захисного механізму проявляється в розрядці пригнічених емоцій (як правило, ворожості, гніву), які спрямовуються на об'єкти, що становлять меншу небезпеку або доступніші, ніж ті, що викликали негативні емоції та почуття. Ймовірно, з віком людина навчається менш «виразним» засобам виразу гніву [1].

Механізм інтелектуалізації (раціоналізації, сублімації) має тенденцію до більшого прояву в середньому віці (I - 0,35 бала; II - 0,41 бала). Дія інтелектуалізації проявляється в надмірно «розумовому» способі подолання конфліктної або фруструючої ситуації без переживань. Іншими словами, особистість присікає переживання, викликані неприємною або суб'єктивно неприйнятною ситуацією за допомогою логічних настанов і маніпуляцій навіть за наявності переконливих доказів на користь протилежного.

Механізм реактивних утворень виявився характернішим для респондентів раннього дорослого віку (I - 0,48 бала; II - 0,41 бала). За допомогою цього механізму особистість запобігає вираз неприємних або неприйнятних для неї думок, почуттів або вчинків шляхом перебільшеного розвитку протилежних прагнень (трансформація внутрішніх імпульсів в їх протилежність).

Для визначення статистично правдивих відмінностей у показниках прояву механізмів психологічного захисту в I та II групах досліджуваних ми використали t-критерій Стьюдента $\left(t_{k p}=2,61\right.$; $\mathrm{p}<0,01)$. Нами виявлено, що прояв певних механізмів психологічного захисту залишається майже незмінним в аспекті віку. Найменш варіативні показники: механізми витіснення, проєкції, регресії, компенсації. До найбільш варіативних показників можна віднести механізми заміщення $\left(t_{\text {eun }}=4,41\right)$, інтелектуалізації $\left(t_{\text {enn }}=2,92\right)$, заперечення $\left(t_{\text {eиn }}=4,65\right)$, реактивних утворень $\left(t_{\text {eмn }}=5,12\right)$. Провідними механізмами психологічного захисту в обох періодах дорослого віку виявилися заперечення, витиснення та регресія.

Перейдемо до розгляду специфіки копінг-поведінки в стресових ситуаціях (за методикою С. Нормана й співавт.). Згідно $з$ отриманими даними, проблемно орієнтований стиль копінгу не піддається віковим змінам людини й залишається впродовж всього періоду дорослості на досить високому рівні (I - 77,02 бала; II - 76,7 бала). Копінг, орієнтований на розв'язання завдання, містить планування, активні дії з розв'язання проблеми. Таким чином, цей вид копінгу, бувши інструментальним та активним за своєю природою, безпосередньо спрямованим на протидію та управління проблемою або джерелом стресу, не залежить від особистісних вікових змін, а зумовлений ситуативними причинами.

У ході дослідження зафіксовано значуще збільшення $з$ віком показника копінгу, орієнтованого на емоиії, який характеризується регулюванням пережитих емоцій і поведінки й не припускає повної свободи дій (I - 49,38 бала; II - 54,96 бала). Емоційно орієнтований стиль копінгу містить занурення в переживання, емоційну розрядку, позитивну переоцінку того, що відбувається, залучення інших у свої переживання. Наростання 3 віком емоційно сфокусованого стилю може бути пов'язано з тим, що у своєму дорослому періоді розвитку людина все більше стикається із ситуаціями, які не можуть бути розв'язані одноразово, ймовірно, для цього може бути не досить інформації, неясне джерело проблем або власні можливості щодо розв'язання. У цьому випадку емоційно орієнтований стиль копінгу $€$ найкращим для людини з позиції підтримки суб'єктивної цілісності й комфорту в тривалій травмувальній ситуації.

Орієнтація на уникнення (відволікання) виявилася вираженішою в групі II періоду дорослості (I - 42,1 бала; II - 44,23 бала). Переважання відволікання в групі II періоду дорослості може бути пов'язано з проявом антиципації загрози й обережною поведінкою. На думку Т.Л. Крюкової [2], уникаючий стиль копінгу проявляється у вигляді відходу від проблеми, спроб не думати про проблему взагалі, бажання забутися уві сні, розчинити свої негаразди в алкоголі або компенсувати негативні емоції їею, сховатися за спиною компетентних людей, які гарантують соціальну підтримку. Крім того, досліджуваний період дорослості пов'язаний із підбиттям перших підсумків життя, оцінюванням ступеня реалізації життєвих завдань, досягнення цілей, поставлених, переважно, в юнацькому віці. Ймовірно, вироблений навик копінгу дозволяє в середньому віці переводити на усвідомлений рівень причини тривоги й суб' єктивного дискомфорту, але водночас реалізація напруги, яка пов'язана з травмувальними подіями, буде здійснюватися у вигляді спроб уникнути травми, зняти із себе відповідальність за те, що відбувається.

Низькі результати відволікання (уникнення) у віковому періоді від 22 до 36 років можна пояснити тим, що в цьому віці відбувається вирівнювання темпів розвитку окремих сторін особистості; в цьому віці людина активно освоюється в професії та в родині. Оскільки здійснювати повноцінне життя людина не може, розвиваючись тільки в одному якомусь напрямі, то в молодості, так само як і в дорослості, їй будуть потрібні всі ресурси своєї особистості, отже, неконструктивність уникаючих стратегій стає очевидною. 
Орієнтація на соиіальне відволікання, навпаки, виявилася вираженішою в групі раннього періоду дорослості (I - 52,82 бала; II - 50,95 бала). Прагнення людини в період ранньої дорослості контактувати 3 іншими людьми у важких ситуаціях передбачає формування підлеглих відносин внаслідок податливості до впливу оточення, сугестивності. Очевидно, цей віковий період характеризується потребою в наставникові, певній особі, яка підтримує.

За допомогою t-критерію Стьюдента $\left(t_{\kappa p}=2,61\right)$ було виявлено статистично правдиві відмінності в показниках прояву стилів копінг-поведінки в I та II групах досліджуваних. Найменш варіативні показники: проблемно орієнтований стиль копінгу, орієнтація на соціальне відволікання. До найваріативніших показників можна віднести емоційно орієнтований стиль копінгу $\left(t_{\text {eun }}=4,57\right)$, орієнтацію на уникнення $\left(t_{\text {eun }}=2,99\right)$. Провідними стилями копінг-поведінки в ранньому дорослому віці виявилися проблемно орієнтований стиль копінгу, орієнтація на соціальне відволікання; в середньому віці - проблемно орієнтований стиль копінгу, емоційно орієнтований стиль копінгу.

Розглянемо результати діагностики стратегій поведінкової активності в стресових умовах (за методикою Л.I. Вассермана, Н.В. Гуменюка).

Стратегія поведінкової активності А характерніша для вікової категорії 21-35 років (I - 54,1 \%; II - 13,7 \%). Слід зазначити, що ця стратегія є домінівною в досліджуваних раннього дорослого віку й характеризує гіперактивних, наденергійних, нетерплячих, імпульсивних особистостей. Для таких людей характерна перебільшена потреба в діяльності, ініціативність, брак часу для відпочинку й розваг, висока мотивація досягнення, змагальність, схильність до суперництва й визнання, амбітність. Такі дані можна пояснити специфікою соціальної ситуації розвитку в ранньому дорослому віці. У цей період людина досягає піку у своєму фізичному розвитку; активно збагачується iii психологічний і соціальний досвід, вона включається в усі види соціальної активності, оволодіває багатьма соціальними ролями.

Показники прояву стратегії поведінкової активності A1 зафіксовано в однаковому числовому діапазоні в обох групах досліджуваних (I $22,95 \%$; II - 28,77 \%). Такі дані вказують на тенденцію до поведінкової активності типу А й характеризують енергійну особистість, яка прагне змагання, без амбіційності й агресивності, з високою діловою активністю, прагнення до успіху й лідерства.

Стратегія поведінкової активності АБ характерніша для вікової категорії 36-60 років (I - 18,03 \%; II $-41,1 \%)$. Слід зазначити, що ця стратегія $\epsilon$ домінівною в досліджуваних середнього віку й характеризує збалансовану, впевнену, емоційно стабільну особистість. Для осіб, в яких діагностується перехідний тип поведінкової активності, характерна активна й цілеспрямована діловитість, різнобічність інтересів, вміння збалансувати ділову активність, напружену роботу зі зміною занять і вміло організованим відпочинком. Особи типу АБ не виявили явної схильності до домінування, але в певних ситуаціях та обставинах впевнено можуть брати на себе роль лідера; їм притаманна емоційна стабільність і передбачуваність у поведінці, відносна стійкість до дії стресогенних чинників, добра пристосованість до різних видів діяльності.

Отримані результати пояснюємо специфікою соціальної ситуації розвитку в період другого етапу дорослості. Основними сторонами життя людини середнього дорослого віку залишаються сімейні стосунки й професійна діяльність. Визначаюча їх соціальна ситуація розвитку - це ситуація реалізації дорослою людиною самої себе, повного розкриття свого потенціалу в професійній діяльності й сімейних стосунках. Центральним новоутворенням періоду середньої дорослості $€$ продуктивність як інтегральне новоутворення: професійна продуктивність і внесок у розвиток i ствердження в житті майбутнього покоління.

Стратегія поведінкової активності Б1 має тенденцію до підвищення в II групі досліджуваних (I - 3,28 \%; II - 12,33 \%). Цей тип стратегії характеризує раціональну, обережну, неспішну особистість із помірною активністю. Слід зазначити, що наявність у $12,33 \%$ респондентів середнього віку цієї стратегії поведінкової активності свідчить про проміжну позицію між типами стратегій АБ і Б.

Показники прояву стратегії поведінкової активності Б зафіксовано в однаковому числовому діапазоні в обох групах досліджуваних (I - 1,64 \%; II - 4,11 \%). Цей тип стратегії поведінкової активності виявився найменш розповсюдженим у респондентів дорослого віку. Стратегія поведінкової активності Б характеризує м'яку особистість, яка схильна до ретельного зважування рішень і мисленнєвої діяльності.

За допомогою $\mathrm{t}$-критерію Стьюдента $\left(t_{\kappa p}=2,61\right)$ було виявлено статистично правдиві відмінності в показниках прояву стилів поведінкової активності в I та II групах досліджуваних. Найменш варіативні показники: стратегії поведінкової активності A1, Б1, Б. До найваріативніших показників можна віднести стратегії поведінкової активності $\mathrm{A}\left(t_{e n n}=3,79\right)$ та АБ $\left(t_{e n n}=5,13\right)$. Провідними стратегіями поведінкової активності в стресових ситуаціях виявилися: тип А - в ранньому дорослому віці (гіперактивність, нетерплячість, імпульсивність), тип АБ - в середньому віці (збалансованість, впевненість, емоційна стабільність). 
Висновки. У статті представлено результати емпіричного дослідження особливостей системи психологічного захисту особистості в різні періоди дорослості. У ході дослідження встановлено, що прояв певних механізмів психологічного захисту залишається майже незмінними в аспекті віку. Найменш варіативні показники: механізми витіснення, проєкції, регресії, компенсації. До найваріативніших показників віднесено механізми заміщення, інтелектуалізації, заперечення, реактивних утворень. Провідними механізмами психологічного захисту в обох періодах дорослого віку виявилися заперечення, витиснення та регресія.

У ході вивчення специфіки прояву стилів копінг-поведінки виявлено, що прояви певних стилів залишається майже незмінними в аспекті віку. Найменш варіативні показники - проблемно орієнтований стиль копінгу, орієнтація на соціальне відволікання. До найваріативніших показників віднесено емоційно орієнтований стиль копінгу й орієнтацію на уникнення. Провідними стилями копінг-поведінки в ранньому дорослому віці виявилися проблемно орієнтований стиль копінгу, орієнтація на соціальне відволікання; в середньому віці - проблемно орієнтований стиль копінгу, емоційно орієнтований стиль копінгу.
Дослідження стратегій поведінкової активності в стресових умовах дозволило виявити, що прояв певних стратегій залишається незмінним в аспекті віку. Найменш варіативні показники стратегії поведінкової активності А1, Б1, Б. До найваріативніших показників можна віднести стратегії поведінкової активності А. Провідними стратегіями поведінкової активності в стресових ситуаціях виявилися: тип А - в ранньому дорослому віці (гіперактивність, нетерплячість, імпульсивність), тип АБ - в середньому віці (збалансованість, впевненість, емоційна стабільність).

За допомогою математико-статистичного аналізу експериментальних даних припущення про те, що система психологічного захисту особистості характеризується певною специфікою в різні періоди дорослості, підтвердилося. Ця специфіка відбивається в динаміці прояву несвідомих (механізмів психологічного захисту) й усвідомлюваних (копінг-стратегії) компонентів психіки.

Перспективним напрямом розвитку наукової проблематики визначено емпіричне вивчення специфіки системи психологічного захисту особистості в дорослому віці в гендерному аспекті, а також вивчення системи психологічного захисту особистості на інших етапах онтогенезу.

\section{ЛIТЕРАТУРА}

1. Грановская Р.М. Психологическая защита. Санкт-Петербург : Речь, 2007. 476 с.

2. Крюкова Т.Л. Психология совладающего поведения в разные периоды жизни : монография. Кострома : Костромской государственный университет им. Н.А. Некрасова, 2010. 296 с.

3. Лапкина Е.В. Защитная система личности в разные периоды взрослости : дисс. ... канд. психол. наук : 19.00.01. Ярославль, 2012. 166 с.

4. Никольская И.М. Совладающее поведение в защитной системе человека. Психология совладающего поведения : материалы Международной науч.практ. конф. Кострома : КГУ им. Н.А. Некрасова, 2007. C. 52-54.

5. Субботина Л.Ю. Структурно-функциональная организация психологической защиты личности : автореф. ... докт. психол. наук : 19.00.03. Ярославль, 2006. 46 с.

6. Гошовська О.Я. Сутнісна специфіка й диференціація психозахисних механізмів особистості. Науковий вісник Мукачівського державного університету. Серія : Педагогіка та психологія. 2015. Вип. 2. С. 155-160.

7. Эриксон Е.Х. Восемь возрастов человека. Детство и Общество. Санкт-Петербург : Речь, 2002. C. $235-259$.

8. Плутчик Р., Келлерман Г., Конт Х. Тест-опросник механизмов психологической защиты (Life Style Index) / адаптация Л.Р. Гребенникова (руководство по использованию). Москва, 1996. 18 с.

9. Фрейд А. Психология Я и защитные механизмы. Санкт-Петербург : Питер, 2016. 160 с.

10. Фрейд 3. Я и Оно. Москва : Эксмо, 2019. 160 с.

11. Яценко Т.С. Особливості взаємозв'язку між свідомою та несвідомою сферами психіки суб'єкта. Неперервна професійна освіта: теорія і практика : науково-методичний журнал. 2002. Вип. 4 (8). C. 99-110.

12. Carver C.S., Scheier M.F., Weintraub J.K. Assessing coping strategies: a theoretically based approach. Journal of Personality and Social Psychology. 1989. V. 56. P. 207-227.

13. Zimmer-Gembeck M.J., Skinner E.A. Adolescents' coping with stress: development and diversity. Prevention Researcher. 2008. No. 15. P. 3-7. 


\section{REFERENCES}

1. Granovskaya, R.M. (2007). Psikhologicheskaya zashchita [Psychological protection.]. SPb. : Rech', 476 p. [in Russian].

2. Kryukova, T.L. (2010). Psikhologiya sovladayushchego povedeniya v raznyye periody zhizni. Monografiya [Psychology of coping behavior in different periods of life. Monograph]. Kostroma. 296 p. [in Russian].

3. Lapkina, Ye.V. (2012). Zashchitnaya sistema lichnosti v raznyye periody vzroslosti [Protective system of personality in different periods of adulthood]. Candidate's thesis. Yaroslavl'. [in Russian].

4. Nikol'skaya, I.M. (2007). Sovladayushcheye povedeniye v zashchitnoy sisteme cheloveka [Coping behavior in the human defense system]. Psikhologiya sovladayushchego povedeniya : materialy Mezhdunarodnoy nauch.-prakt. konf. Kostroma : KGU im. N.A. Nekrasova. P. 52-54. [in Russian].

5. Subbotina, L.YU. (2006). Strukturno-funktsional'naya organizatsiya psikhologicheskoy zashchity lichnosti [Structural and functional organization of psychological protection of the individual]. Doctor's thesis. Yaroslavl', 2006. [in Russian].

6. Hoshovs'ka, O.YA. (2015). Sutnisna spetsyfika y dyferentsiatsiya psykhozakhysnykh mekhanizmiv osobystosti [Essential specificity and differentiation of psychoprotective mechanisms of personality]. Naukovyy visnyk Mukachivs'koho derzhavnoho universytetu. Seriya : Pedahohika ta psykholohiya. Vyp. 2. P. 155-160. [in Ukrainian].

7. Erikson, Ye.KH. (2002). Vosem' vozrastov cheloveka. Detstvo i Obshchestvo. [Eight human ages. Childhood and Society]. SPb. : Rech'. P. 235-259. [in Russian].

8. Plutchik, R., Kellerman, G., Kont, Kh. (1996). Test-oprosnik mekhanizmov psikhologicheskoy zashchity (Life Style Index) [Test questionnaire of psychological defense mechanisms (Life Style Index)]. Adaptatsiya L.R. Grebennikova (rukovodstvo po ispol'zovaniyu). M., 18 p. [in Russian].

9. Freud, A. (2016). Psikhologiya Ya i zashchitnyye mekhanizmy [The Ego and the Mechanisms of Defence]. $\mathrm{SPb}$. : Piter. 160 p. [in Russian].

10. Freyd Z. (2019). Ya i Ono [The Ego and the Id]. M. : Eksmo.160 p. [in Russian].

11. Yatsenko, T.S. (2002). Osoblyvosti vzayemozv'yazku mizh svidomoyu ta nesvidomoyu sferamy psykhiky sub'yekta [Features of the relationship between the conscious and unconscious spheres of the subject's psyche]. Neperervna profesiyna osvita: teoriya i praktyka : naukovo-metodychnyy zhurnal. Vyp.4 (8). P. 99-110. [in Ukrainian].

12. Carver, C. S., Scheier, M. F. \& Weintraub, J. K. (1989). Assessing coping strategies: a theoretically based approach. Journal of Personality and Social Psychology. V. 56. P. 207-227.

13. Zimmer-Gembeck, M. J., \& Skinner, E. A. (2008). Adolescents' coping with stress: development and diversity. Prevention Researcher, 15, p. 3-7. 